\title{
中国森林生态系统固碳现状、速率和潜力研究
}

周国逸

中国科学院华南植物园, 广州 510650

引用格式: 周国逸 (2016). 中国森林生态系统固碳现状、速率和潜力研究. 植物生态学报, 40, 279-281. doi: 10.17521/cjpe.2016.0132

\section{Evaluation on the carbon pools of China's forest ecosystems-current status, capacities and sinks and studies on the mechanisms}

ZHOU Guo-Yi ${ }^{*}$

South China Botanical Garden, Chinese Academy of Sciences, Guangzhou 510650, China

Citation: ZHOU GY (2016). Evaluation on the carbon pools of China's forest ecosystems-current status, capacities and sinks and studies on the mechanisms. Chinese Journal of Plant Ecology, 40, 279-281. doi: 10.17521/cjpe.2016.0132

森林生态系统是陆地生物圈的主体, 由于其巨 大的碳库和较高的生产力, 在调节全球碳平衡、减 缓大气中 $\mathrm{CO}_{2}$ 等温室气体浓度上升以及维持全球气 候稳定等方面具有不可替代的作用(Kauppi et al., 1992; Dixon et al., 1994; Pan et al., 2011, 2013)。中国 气候类型多样、地形地貌复杂(李炳元等, 2013), 森 林面积广阔、类型繁多且受到不同区域人为干扰和 经营管理措施的影响(Fang et al., 2001; Guo et al., 2013), 这些因素给准确评估中国森林生态系统的 碳储量现状、潜力与固碳速率及其相应的机制研究 带来巨大的挑战。这个挑战摆在中国科学院战略性 先导科技专项“应对气候变化碳收支认证及相关问 题”的“中国森林生态系统固碳现状、速率、机制和 潜力”课题的面前。

以生态系统为单元阐明中国森林生态系统固碳 现状、潜力与速率是专项对课题的基本要求。在本 课题的人力、财力、物力所允许的范围内布设准确 反映全国森林生态系统现状并符合国际标准的野外 调查样地是本课题遇到的第一个挑战, 得益于国家 定期开展的森林资源清查、中国植被分布图、中国 土壤类型图等资料, 我们在全面掌握中国森林蓄积 量、植被类型和土壤类型的详细空间分布的基础上， 布设了7 800 个调查样地, 并多方面论证了其准确 性。本课题的第二个挑战是制订一套统一的、国际 认可的、适应于全国复杂多样的森林生态系统在碳 贮量研究方面的方法体系, 包括样地调查方法、样
品采集和拒存方法、实验室分析方法、生物量与碳 咜量估算方法、数据集成方法等, 并且在课题实施 中必须得到完全的执行, 这套方法通过了多方的论 证并已编辑出版(图1)。参与本课题野外调查的人员 超过 1000 人, 密集的野外调查时间 3 年有余, 其野 外工作之艰辛、安全保障之复杂、组织协调之难度 成为第三个挑战, 至今, 野外调查工作遍及全部样 地却没有发生一起事故, 这令我心存感激。课题获 得了海量数据并汇集成一个庞大的数据库, 数据的 校验与格式归一化是一项浩繁的工作, 从获得第一 批数据开始, 我们就在进行这项工作, 迄今已逾 5 年, 这是本课题的第四个挑战。本课题布设的样地 系统、制订的方法体系、获得的生物量估算方程可 用于未来森林碳循环研究和碳库清查, 保存的样品 可为未来相关研究提供借鉴。本课题培养了一大批 青年学生, 在参与调查的人员中普及了森林生态系 统碳循环的相关知识。通过本课题获得的大量数据 正在为国家和地方的宏观决策提供支撑, 基于数据 的深入挖掘和研究也将获得一批重要的成果。

本专辑共收录13篇研究论文, 所研究的对象和 用到的数据都在省市尺度以下。内容涉及典型森林 生态系统碳格局精细研究(杜虎等, 2016; 范春楠等, 2016; 关晋宏等, 2016; 赵玮等, 2016; 杨怀等, 2016), 利用样地调查和多期森林资源清查资料估算区域尺 度森林固碳现状(范春楠等, 2016; 黄晓琼等, 2016; 李银等, 2016; 王建等, 2016; 许文强等, 2016)、速率

收稿日期Received: 2016-04-12 接受日期Accepted: 2016-04-18

* E-mail: gyzhou@scib.ac.cn 


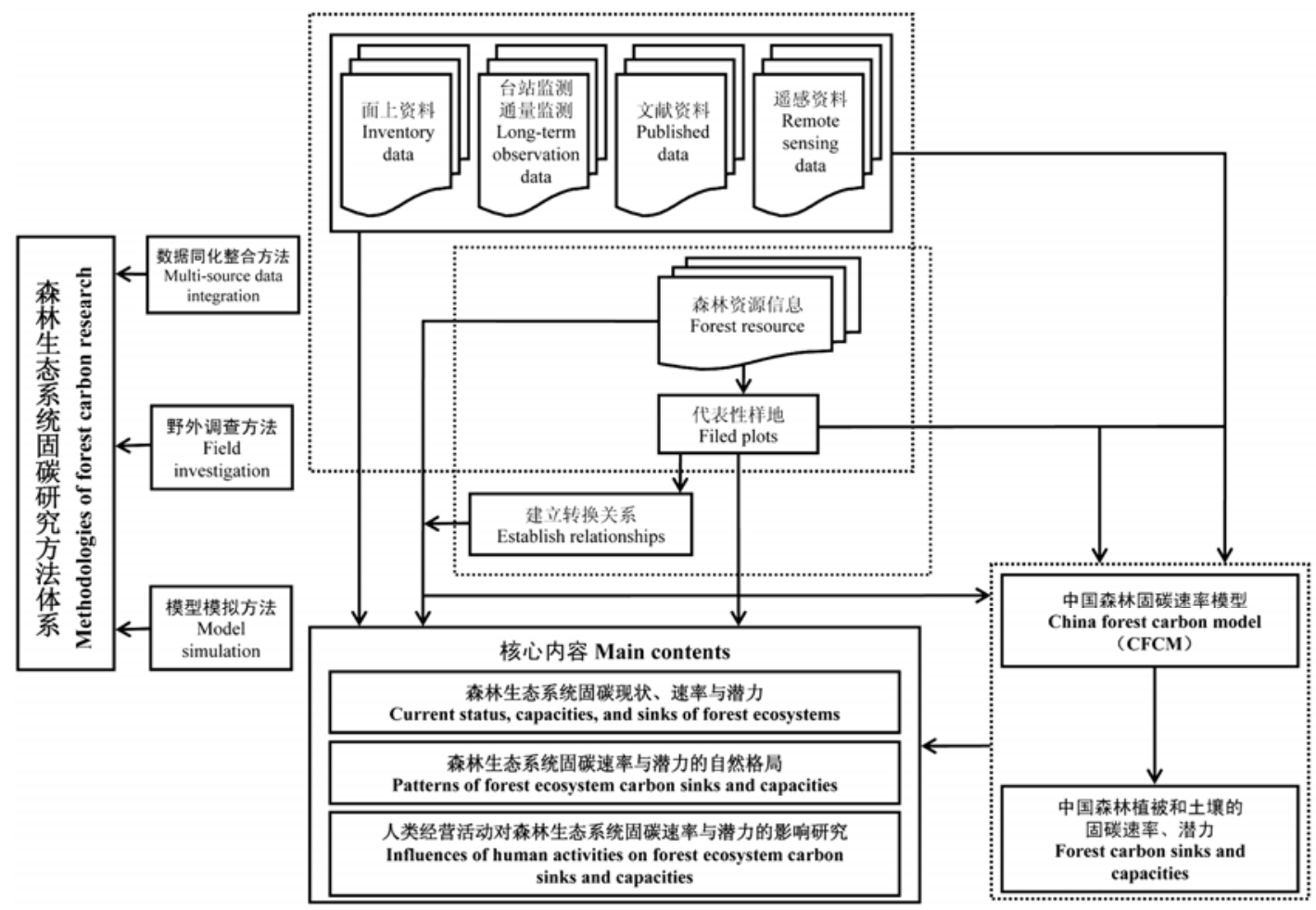

图 1 中国森林生态系统固碳现状、速率和潜力研究的核心内容和技术途径。

Fig. 1 Research contents and technological approaches to evaluate the carbon storages, sinks and capacities of China's forest ecosystems.

(范春楠等, 2016; 王建等, 2016)和固碳潜力(汲玉河 等, 2016; 王建等, 2016), 将实测资料与遥感数据相 结合评估城市森林碳汇(王紫君等, 2016), 模型模拟 森林生态系统固碳速率(贾彦龙等, 2016)及其对气 候变化的响应等(黄玫等, 2016)。

尽管本专辑的文章没有涵盖我国所有森林生态 系统, 但通过对典型森林生态系统代表性样地的精 细调查获得的碳格局, 可以为将来数据融合、区域 或全国尺度集成分析、模型模拟提供大量信息。深 入挖掘这些数据将有助于全面评估我国森林生态系 统固碳现状、速率, 预测其固碳潜力, 探讨森林生态 系统固碳机制。

基金项目中国科学院战略性先导科技专项 (XDA5050200)。

致谢 感谢专项、项目首席科学家对本课题的指 导, 感谢生态系统固碳项目群的研究骨干在本课题 开展和实施过程中给予的建议和帮助, 感谢本课题 的所有参与人员。课题秘书为唐旭利、王万同; 子 课题负责人为韩士杰、杜盛、李胜功、马克平、间 俊华、王根绪、马友金、黄玫; 承担各省市任务的 负责人为胡远满、韩士杰、于大炮、胡中民、杜 盛、程积民、杨辽、许文强、桑卫国、肖玉、周才 平、李胜功、高贤明、陈云明、刘春江、田兴军、
马克平、郭柯、徐小牛、江明喜、包维楷、郑元 润、温达志、李志安、张德强、曾馥平、汪思龙、 问俊华、马友拿、任海、王长庭、王根绪。本课题 任务书中有281人, 请原谅这里不能一一列出名单。

\section{参考文献}

Dixon RK, Solomon AM, Brown S, Houghton RA, Trexier MC, Wisniewski J (1994). Carbon pools and flux of global forest ecosystem. Science, 263, 185-190.

Du H, Zeng FP, Song TQ, Wen YG, Li CG, Peng WX, Zhang H, Zeng ZX (2016). Spatial pattern of soil organic carbon of the main forest soils and its influencing factors in Guangxi, China. Chinese Journal of Plant Ecology, 40, 282-291. (in Chinese with English abstract) [杜虎, 曾馥 平, 宋同清, 温远光, 李春干, 彭晚霞, 张浩, 曾昭霞 (2016). 广西主要森林土壤有机碳空间分布及其影响因 素. 植物生态学报, 40, 282-291.]

Fan CN, Han SJ, Guo ZL, Zheng JP, Cheng Y (2016). Present status and rate of carbon sequestration of forest vegetation in Jilin Province, Northeast China. Chinese Journal of Plant Ecology, 40, 341-353. (in Chinese with English abstract) [范 春楠, 韩士杰, 郭忠玲, 郑金萍, 程岩 (2016). 吉林省森 林植被固碳现状与速率. 植物生态学报, 40, 341-353.]

Fang JY, Chen AP, Peng CH, Zhao SQ, Ci LJ (2001). Changes in forest biomass carbon storage in China between 1949 and 1998. Science, 292, 2320-2322.

Guan JH, Du S, Cheng JM, Wu CR, Li GQ, Deng L, Zhang JG, www.plant-ecology.com 
He QY, Shi WY (2016). Current stocks and rate of sequestration of forest carbon in Gansu Province, China. Chinese Journal of Plant Ecology, 40, 304-317. (in Chinese with English abstract) [关晋宏, 杜盛, 程积民, 吴春荣, 李国 庆, 邓否, 张建国, 何秋月, 时伟宇 (2016). 甘肃省森林 碳储量现状与固碳速率. 植物生态学报, 40, 304-317.]

Guo ZD, Hu HF, Li P, Li NY, Fang JY (2013). Spatio-temporal changes in biomass carbon sinks in China's forests during 1977-2008. Science in China: Life Sciences, 56, 661-671.

Huang M, Hou J, Tang XL, Hao M (2016). Response of vegetation and soil carbon accumulation rate for China's mature forest on climate change. Chinese Journal of Plant Ecology, 40, 416-424. (in Chinese with English abstract) [黄玫, 侯 晶, 唐旭利, 郝曼 (2016). 中国成熟林植被和土壤固碳 速率对气候变化的响应. 植物生态学报, 40, 416-424.]

Huang XQ, Xin CL, Hu ZM, Li GT, Zhang TH, Zhao W, Yang H, Zhang LM, Guo Q, Yue YJ, Gao RH, Wu ZY, Yan ZG, Liu XP, Li YQ, Li SG (2016). Carbon storage of the forests and its spatial pattern in Nei Mongol, China. Chinese Journal of Plant Ecology, 40, 327-340. (in Chinese with English abstract) [黄晓琼, 辛存林, 胡中民, 李钢铁, 张铜会, 赵 玮, 杨浩, 张雷明, 郭群, 岳永杰, 高润宏, 乌志颜, 间志 刚, 刘新平, 李玉强, 李胜功 (2016). 内蒙古森林生态系 统碳储量及其空间分布. 植物生态学报, 40, 327-340.]

Ji YH, Guo K, Ni J, Xu XN, Wang ZG, Wang SD (2016). Current forest carbon stocks and carbon sequestration potential in Anhui Province, China. Chinese Journal of Plant Ecology, 40, 395-404. (in Chinese with English abstract) [汲玉河, 郭 柯, 倪健, 徐小牛, 王志高, 王树东 (2016). 安徽省森林 碳储量现状及固碳潜力. 植物生态学报, 40, 395-404.]

Jia YL, Li QR, Xu ZQ, Sang WG (2016). Carbon cycle of larch plantation based on CO2FIX model. Chinese Journal of Plant Ecology, 40, 405-415. (in Chinese with English abstract) [贾彦龙, 李倩茹, 许中旗, 桑卫国 (2016). 基于 CO2FIX模型的华北落叶松人工林碳循环过程. 植物生 态学报, 40, 405-415.]

Kauppi PE, Mielikainen K, Kusela K (1992). Biomass and carbon budget of European forests, 1971-1990. Science, 256, 70-74.

Li BY, Pan BT, Cheng WM, Han JF, Qi DL, Zhu C (2013). Research on geomorphological regionalization of China. Acta Geographica Sinica, 68, 291-306. (in Chinese with English abstract) [李炳元, 潘保田, 程维明, 韩嘉福, 齐德利, 朱 澈 (2013). 中国地貌区划新论. 地理学报, 68, 291-306.]

Li Y, Chen GK, Lin DM, Chen B, Gao LM, Jian X, Yang B, Xu WB, Su HX, Lai JS, Wang XH, Yang HB, Ma KP (2016). Carbon storage and its distribution of forest ecosystems in Zhejiang Province, China. Chinese Journal of Plant Ecology, 40, 354-363. (in Chinese with English abstract) [李银, 陈国科，林敦梅，陈樹，高雷明，简兴，杨波，徐武兵，苏 宏新，赖江山，王希华，杨海波，马克平 (2016). 浙江
省森林生态系统碳储量及其分布特征. 植物生态学报, 40, 354-363.]

Pan Y, Birdsey RA, Fang JY, Houghton R, Kauppi PE, Kurz WA, Phillips OL, Shvidenko A, Lweis SL, Canadell JG, Ciais P, Jackson RB, Pacala SW, McGuire AD, Piao SL, Rautiainen A, Sitch S, Hayes D (2011). A large and persistent carbon sink in the world's forests. Science, 333, 988-993.

Pan YD, Birdsey RA, Phillips OL, Jackson RB (2013). The structure, distribution, and biomass of the world's forests. Annual Review of Ecology, Evolution, and Systematics, 44, 593-622.

Wang J, Wang GX, Wang CT, Ran F, Chang RY (2016). Carbon storage and potentials of the broad-leaved forest in alpine region of the Qinghai-Xizang Plateau, China. Chinese Journal of Plant Ecology, 40, 374-384. (in Chinese with English abstract) [王建, 王根绪, 王长庭, 苒飞, 常瑞英 (2016). 青藏高原高寒区阔叶林植被固碳现状、速率和 潜力. 植物生态学报, 40, 374-384.]

Wang ZJ, Shen GR, Zhu Y, Han YJ, Liu CJ, Wang Z, Xue CY (2016). Research on characteristics of biomass distribution in urban forests of Shanghai metropolis based on remote sensing and spatial analysis. Chinese Journal of Plant Ecology, 40, 385-394. (in Chinese with English abstract) [王紫君, 申广荣, 朱望, 韩玉洁, 刘春江, 王哲, 薛春 燕 (2016). 基于遥感和空间分析的上海城市森林生物 量分布特征. 植物生态学报, 40, 385-394.]

Xu WQ, Yang L, Chen X, Gao YQ, Wang L (2016). Carbon storage, spatial distribution and the influence factors in Tianshan forests. Chinese Journal of Plant Ecology, 40, 364-373. (in Chinese with English abstract) [许文强, 杨 辽, 陈䂀, 高亚琪, 王蕾 (2016). 天山森林生态系统碳 储量格局及其影响因素. 植物生态学报, 40, 364-373.]

Yang H, Li YD, Ren H, Luo TS, Chen RL, Liu WJ, Chen DX, $\mathrm{Xu} \mathrm{H}$, Zhou Z, Lin MX, Yang Q, Yao HR, Zhou GY (2016). Soil organic carbon density and influencing factors in tropical virgin forests of Hainan Island, China. Chinese Journal of Plant Ecology, 40, 292-303. (in Chinese with English abstract) [杨怀, 李意德, 任海, 骆土寿, 陈仁利, 刘文杰，陈德祥，许涵，周璋，林明献，杨秋，姚海荣， 周国逸 (2016). 海南岛热带原始森林主要分布区土壤 有机碳密度及影响因素. 植物生态学报, 40, 292-303.]

Zhao W, Hu ZM, Yang H, Zhang LM, Guo Q, Wu ZY, Liu DY, Li SG (2016). Carbon density characteristics of sparse Ulmus pumila forest and Populus simonii plantation in Onqin Daga Sandy Land and their relationships with stand age. Chinese Journal of Plant Ecology, 40, 318-326. (in Chinese with English abstract) [赵玮, 胡中民, 杨浩, 张 雷明, 郭群, 乌志颜, 刘德义, 李胜功 (2016). 浑善达 克沙地榆树疏林和小叶杨人工林碳密度特征及其与林 龄的关系. 植物生态学报, 40, 318-326.]

责任编辑：谢 巍 


\begin{tabular}{|c|c|c|}
\hline 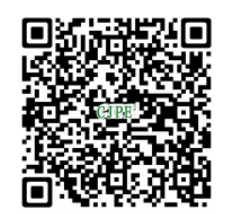 & 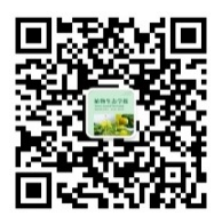 & 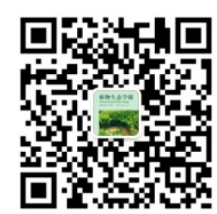 \\
\hline 植物生 & & \\
\hline & $\begin{array}{c}\text { 期刊及学科 } \\
\text { 相关信息发布 }\end{array}$ & $\begin{array}{l}\text { 稿件状态查询 } \\
\text { 全文检索测览 }\end{array}$ \\
\hline
\end{tabular}

